Є. В. Волянська

\title{
СЛОВОТВІРНА МОРФОНОЛОГІЯ ВІДСУБСТАНТИВНИХ НОВИХ СЛІВ В УКРАЇНСЬКІЙ І РОСІЙСЬКІЙ МОВАХ
}

Волянська Є. В. Словотвірна морфонологія відсубстантивних нових слів в українській і російських мовах.

У статті проаналізовано нові слова української і російської мов, виявлено продуктивні морфонологічні явища нових слів та порівняно особливості та закономірності їхнього творення в українській та російській мовах.

Ключові слова: відсубстантиви, морфонологічні явища, чергування фонем, зміна акцентуації.

Волянская Е. В. Словообразовательная морфонология отсубстантивных новых слов в украинском и русском языках.

В статье проанализированы новые слова украинского и русского языков, обнаружены продуктивные морфонологические явления новых слов и сравнены особенности и закономерности их образования в украинском и русском языках.

Ключевые слова: отсубстантивы, морфонологические явления, чередование фонем, изменение акцентуации.

Volianska. I. V. Derivational morphonology of the substantive new words in Ukrainian and Russian languages.

The article analyzes the new words of modern Ukrainian and Russian, the productive morfonological phenomena of the new words are found, the specific features and patterns of their creation are compared in modern Ukrainian and Russian languages.

Key words: noun derivatives, morfonological phenomena, phoneme alternations, change of accentuation.

Виявлення особливостей та основних тенденцій розвитку словотвірної системи певної мови належить до актуальних завдань сучасної лінгвістики. Його розв'язання неможливе без дослідження дериваційної системи на синхронному зрізі. Завдяки словотворенню мова постійно реалізує свої можливості в забезпеченні комунікативних потреб суспільства. Спостереження над шляхами розвитку лексичного складу мови сучасних 
ЗМІ засвідчують, що традиційно одним із важливих джерел лексичного збагачення було й залишається словотворення, тобто реалізація потенційних можливостей, закладених у цій підсистемі національної мови. Спираючись на власні словотворчі ресурси, а також запозичуючи певну частину їх з інших мов, українська дериваційна система формує значний потенціал для утворення різноманітних лексичних одиниць.

Проблемам словотвірної морфонології присвячені праці М. С. Трубецького, Г. Улашина, І. О. Бодуена де Куртене, М. В. Крушевського, О. О. Реформатського, I. І. Ковалика, Р. І. Аванесова, Я. Босака, В. Дресслера, К. Ковалик, Р. Лясковського, С. М. Толстої, О. А. Земської, В. Г. Чурганової, В.В.Лопатіна, Н. Є. Ільїної, В. Б. Касевича, Л. Е. Калнинь, Ю. Г. Панкраца, Т. В. Попової, Т. В. Булигіної, І. С. Улуханова, Л. М. Полюги, Н. Ф. Клименко, В. О. Горпинича, К. Г. Городенської, М. В. Кравченко, 3. С. Сікорської, С. А. Карпіловської, О. Ф. Пінчука, М. Ю. Федурко, І. В. Козленко, Л. І. Комарової, Л. О. Кондакової, I. М. Демешко, С. М. Єлдінової, Г. М. Потапової, Г. В. Пристай та ін.

Мета пропонованої розвідки - установити морфонологічні ознаки відсубстантивних нових слів в українській і російській мовах. I3 поставленої мети випливають такі конкретні завдання: 1) проаналізувати морфонологічні ознаки відсубстантивних неолексем в українській i російській мовах; 2) виявити продуктивні морфонологічні явища нових слів; 3) порівняти особливості та закономірності їхнього творення в українській та російській мовах.

У сучасній лінгвістиці морфонологи зосереджують увагу на загальнотеоретичних питаннях аналізу морфонологічних систем мов із високою регулярністю формальної модифікації морфем. У загальнотеоретичному плані значну роль для побудови єдиної граматичної системи частин мови відіграє дослідження словотвірної морфонології нових лексем в українській і російській мовах.

Зміна стану й статусу української мови в другій половині 80-х-90-х років XX ст. сприяла активізації в ній інноваційних словотвірних процесів. Проте активні словотвірні процеси сучасності зафіксовані і в інших слов'янських мовах, зокрема в російській. Неологізми останніх років найбільш повно освітлені в монографії - Русский язык конца XX столетия (М., 1996), у розділі, написаному О. А. Земською, у працях В. Г. Костомарова, В. М. Шапошникова. Тому вбачаємо за доцільне порівняти особливості сучасних словотвірних процесів в українській та російській мовах.

Серед усіх відомих функцій деривації в аналізований період, як відзначають дослідники, особливо помітні номінативна, експресивна та компресивна [3, с. 168]. У мові засобів масової інформації найвиразніше виявляється експресивна функція словотворення, підпорядковуючи собі номінативну та компресивну функції. Це зумовлено нейтралізацією експресивних засобів висловлювання, характерних для попереднього (с) Є. В. Волянська, 2013. 
періоду розвитку досліджуваного функціонального різновиду мови i пошуками нових виражально-зображальних одиниць. Джерелом поповнення останніх $є$ передусім словотворення нових слів у розмовному стилі, а також оказіональні лексичні новотвори в художньому та публіцистичному стилях. Дослідники слушно відзначають домінування зниженої експресії, що зумовлено суспільно-політичними змінами комунікації і виробленням нових стандартів масової інформації.

Найбільшу групу інновацій у мові сучасних мас-медіа української та російської мов становлять іменники, утворення яких зумовлене потребою номінації осіб, нових явищ та предметів. Кількісну перевагу іменників над одиницями інших лексико-граматичних класів потрібно розглядати як універсалію новітнього мовного розвитку. Це породжено, на думку дослідників, загальною тенденцією до номіналізації в багатьох мовах: в українській (К. В. Ленець, Г. М. Віняр, Т. А. Коць, Д. В. Мазурик), у російській (О.А. Земська, Л. Ферм, В.Г. Костомаров, в англійській (В. І. Заботкіна, Ю. А. Зацний), у болгарській (А. В. Березовенко та ін.).

Високою продуктивністю в іменниковому інноваційному словотворі відзначається суфіксальний спосіб. У дериваційних процесах використовуються лише деякі словотвірні типи, наявні в суфіксальній підсистемі української та російської мов. Суфіксальні іменники тематично різнопланові. Вони об'єднують назви осіб (агентивів), опредметнених дій, абстрактних понять, а також номінації предметів, матеріалів і речовин.

Найактивніше поповнюється тематична група іменників на позначення осіб. Її новотвори є переконливим свідченням тісної взаємодії насамперед екстралінгвальних чинників із власне мовними. Позамовні чинники сприяли динамічному продукуванню лексем цієї групи, що зумовлено постійною потребою номінації (нерідко прагматичного характеру) нових осіб, зокрема за належністю до певної соціальної групи, організації, об'єднання за певним видом занять чи якоюсь іншою специфічною особливістю. Внутрішньомовні чинники не перешкоджають входженню зазначених новотворів до лексичної системи української мови, оскільки процес деривації відбувається за наявними в українській мові словотвірними типами і моделями, а також морфонологічними змінами, що супроводжують процес словотворення. Для відтворення нових особливостей i реалій життя української спільноти останнім часом утворено такі лексичні одиниці, як державотворецьь, посадовець, державобудівник, ринковик, бізнесовець, пікетувальник.

Серед інноваційних субстантивів порівняно значну групу становлять відсубстантивні деривати. Вони позначають діячів як чоловічої, так і жіночої статі. Словотвірний тип (СТ) із суфіксом -ець-івець охоплює іменники, що вказують на належність до певного ідеологічного, суспільно-політичного напрямку, угрупування, блоку, фракції, на відношення до установи, 
організації, спортивної команди, військово-патріотичної виховної організації, підприємства, вокально-інструментального ансамблю, художнього колективу, банку тощо: грінпісівещь, громадівещь, рухівець, київрадівець, беркутівець, відродженець, світочівець, факсівець, баскетівець, тризубівець, грінгреївечь, океанещь, піккардієць, скрябінець, приватбанківещь, авалівець та ін. Наприклад: Сам ветеран набрав у сумі 31 очко, ще 17 приніс «баскетівцям» Козоріз (СТБ : Вікна, 27.06.13).

Значно розширилося коло похідних основ як у сучасному українському, так і в російському словотворенні за рахунок антропонімів, серед яких домінують нові лексеми, що постали на основі відомих прізвищ українських політиків та громадських діячів (кравчуківець, кучмівець, удовенківець, костенківець, симоненківещь, вітренківещь, морозівещь, марчуківещь, пинзенківець); представників культури і літератури (реріховещь, лукашівещь); злочинних угруповань (савлохівець); представників та засновників різноманітних конфесій та сект (філаретівець, сабоданівець, силенкіанещь, мунівець) та ін., а також прізвищ представників закордонної еліти (горбачовещь, лужковець, жириновець, баркашовець, зюгановець, лукашенківецьь, клінтонівець) тощо. У наведених вище прикладах спостерігаємо морфонологічні консонантні

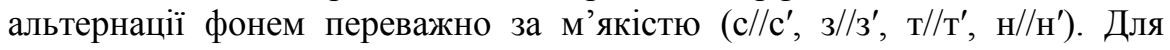
відсубстантивних похідних продуктивною є позиція палаталізації.

На думку О. А. Земської, активний вибір власних імен як базових основ словотворення зумовлений посиленням особистісного начала, що $\epsilon$ характерною ознакою мови нашого часу [5, с. 99]. Нові слова, мотивовані власними іменами, у російській мові з'являються не поодиноко, а цілими групами. Так, ім'я та прізвище Бориса Сльцина мотивують такі нові лексеми, як ельциинец, ельц̧инист, антиельц̧инист, ельцинолюб, ельциноид, ельцинолюбие, ельцинофобия, ельциноборчество; Борисбург, Ельцинбург. В останні роки в пресі активно обігрується прізвище президента Путіна: Европа взялась за "Путиниану" (КП, 03.10.12); Станет ли Питер «Путинбургом?» (КП, 16.03.12). Прізвище президента породжує значну кількість політичних понять, наприклад: путинг, путиномика, Путиненко, вернопутинство. У наведених прикладах домінує таке морфонологічне явище як зміна акцентної позиції з кореневої морфеми на афіксальну (Е'льцин - е́льцинец, ельцини́ст, антиельцини́ст), або на другу частину складних слів (Борисбу́рг, Ельциинбу́рг, ельцинолю'б, ельщинолю'бие, ельцчинофо́бия, ельцинобо́рчество) [4, с. 75-76].

Помітно активізувалося вживання відабревіатурних утворень (переважно від літерних і звукових) із суфіксом -ець-івець, що означають представників та прибічників певних міжнародних, міждержавних союзів, спортивних організацій, ліг, конфесійних угруповань і течій, а також новостворених в Україні партій, рухів, об'єднань, блоків, комітетів, силових органів, газет та ін.: МВФ-емвеефівець, СНД-есендівець/СНДівець, КПСС-капеесесівець ๑ Є. В. Волянська, 2013. 
відбувається консонантні альтернації фонем на морфемному шві (д//д', с//с').

Поступово зростає продуктивність відсубстантивних інновацій СТ із демінутивним суфіксом -яm-(a): беркутята (представники дитячої спортивної секції, яка діє при загоні міліції швидкого реагування «Беркут»), суменята (юні прихильники СУМу - Спілки української молоді), «Снігурята» (назва мультфільму) (від снігур) тощо, наприклад: Усе наше членство поділене на п'ять категорій. С так звані «суменята» - ие діти y віці від 4 до 6 років (Народна газета, 37, вересень, 1993) [6, с. 130]. Приєднання суфіксів у певних випадках може супроводжуватися порушеннями обмежень у сполучуваності морфем і тим самим відхиленнями від тих чи тих словотвірних типів. У російській мові суфікс -am(a) зі значенням недорослості приєднується до основ іменників на позначення неістот. Так, в іменнику жигулята відбувається відхилення від мовної норми, оскільки суфікс приєднується до основи $з$ іншою семантикою: В прошлую субботу с пяти вечера к входу в Кремлевский кониертный зал стали съезжаться крутые иномарки, разноиветные «Волги» $u$ nотрепанные «жсиулята» (Нижнегородский рабочий, 05.03.2002). "Москвичата» находят свой покой где-нибудь во дворах, кюветах или на nустырях (КП - Нижний Новгород, 25.08.2001). В українській мові, на відміну від російської, спостерігаємо морфонологічні альтернації фонем, для яких характерними є морфонологічні позиції палатальності / депалатальності.

Помітна тенденція до активного творення і функціонування іменників на позначення абстрактної дії, що є характерною ознакою інтелектуалізації української мови, впливу на лінгвальну практику сучасної публіцистики, наукового стилю. Своєрідною ознакою деяких із цих іменників $є$ те, що їхня деривація відбулася без опори на дієслівну твірну основу. У мовознавчій літературі це явище кваліфікують як черезступінчате творення на основі імен (пор.: бартер - бартеризачія, валюта - валютизація, долар доларизачія, манкурт - манкуртизація, жлоб - жлобалізація, кілер кілеризація), що зумовлено характером вираженої дії, яка відбувається здебільшого безвідносно до діяча, через що не завжди потребує дієслівного оформлення [1, с.10]. Таке нове словотвірне явище було засвідчене в російській мові в 60-і роки XX ст. [5, с. 104]. Так, оказіоналізм стильниць:: Эта одежда придется по вкусу даже не столько модницам, сколько «стильницам» (АиФ - Нижний Новгород, 1996, № 16) ілюструє структуру слова-зразка моднищы, випускаючи словотвірну ланку твірного ім. зі значенням особи чоловічого роду [4, с. 102].

Названі новотвори української мови відбивають аналогійні процеси в деривації, тобто творення слів за наявними в мові типами, моделями без опори на системні твірні основи. Як зауважує Г. М. Віняр, аналогійні процеси зумовлюють зрушення у відношеннях мотивації у словотвірному ланцюжку «іменник, прикметник - відіменне дієслово - віддієслівний 
іменник (назва опредметненої дії) спостерігається пропуск ступеня деривації дієслова i безпосереднє творення іменників - назв дії мотивувальних імен. На рівні діахронії це засвідчує наявність мотиваційних відношень «іменник, прикметник - іменник 3 процесуальним значенням», що $є$ фактом об'єднання в одному словотвірному акті лексичної i синтаксичної деривації, процесом вербалізації і транскатегоризації назв дії до класу іменників» [1, с. 120].

У лінгвальній практиці української публіцистики останнього десятиліття активно утворюються оказіональні іменники на -ізацій-/-изаційвід назв континентів, регіонів, держав, народів, прізвищ відомих діячів та ін.: югославізація, балканізачія, афганізація, білорусизаџія, сербізаџія, лукашенкізація, суркісизаџія, макдональдизаџія тощо. У наведених прикладах спостерігаємо зсув наголосу (переміщення акцентної позиції) з кореневої на суфіксальну морфему: Югосла́вія - югославіза́иія, Балка́ни - балканіза́иія, Афганіста́н - афганіза́uฺiя. У деяких прикладах трапляється зміна акцентної позиції та консонантні альтернації фонем (застосування альтернацій $\mathrm{H} / \mathrm{H}^{\prime}$ (Балка́ни - балканіза́ція) і С'//C (Білору'сія - білорусиза'ція). Ці іменники поповнили потенціал експресивних виражальних засобів, які пожвавлюють, урізноманітнюють виклад інформації, надають йому розмовного характеру: Хто ж стоїть за «балканізацією" Украӥни, легше зрозуміти, коли простежсти, як розбрат регіоналізують на Захід - Центр, Північ - Схід Південний Схід - Крим (Народна газета, №6, 94); У наземних операціях сербські війська зможуть протистояти силам НАТО ефективніше, ніж y повітрі. Це може призвести до афганізації, тобто затягування конфлікту (УіСС, 14-20.05.99); "Суркісизація» українського шкіряного м'яча (назва статті) (За вільну Україну, 18.08.2000) [6, с. 134].

У друкованих та електронних ЗМІ спостерігаємо співвідносне вживання словотвірних типів на -ізацій-/-изацій-, -ацій- та утворень із суфіксом -н'н'-. Так, поряд з іменниками структуриза́ція, комп'ютериза́ція, зомбіза́ція, політиза́ція, спонсориза́ція паралельно функціонують кореляти структурува́ння, комп'ютеризува́ння, зомбува́ння, політизува́ння, спонсоризува́ння. У цих прикладах також наявне морфонологічне явище зміна акцентних позицій. Надання переваги питомим українським дериватам уже окреслилося в деяких мас-медіа демократичної орієнтації, наприклад, у газетах «Літературна Україна», «Вечірній Київ», «Українське слово», «Народна газета», «Україна молода», «Слово і час» та в ін.: Чи вдаються украӥнські мас-медіа до зомбува́ння людей в Украӥні? (Україна молода, 26.12.2012); Гроші, щзо йдуть на спонсорува́ння культури, будуть звільнятися від податку (Україна молода, 29.01.2011).

У творенні нових слів граматичний, словотвірний, лексичний, етимологічний, евфонічний чинники виконують супровідну роль, однак при цьому вкрай важливо враховувати морфонологічний чинник: ๑ Є. В. Волянська, 2013. 
Двоповерховий сучасний дім з вежкою та сантабарбарівськими (p//p') колонами був огороджений \{Д Дж\} півторакілометровим муром $i$ обладнаний системою стеження (О. Думанська). Для морфонологічної позиції палаталізації характерний досить широкий діапазон дії і створені відповідні умови для ії застосування [2, с. 47].

За останні роки в мові ЗМІ України та Росії розширився корпус іменникових новотворів, оформлених за допомогою іншомовних інтернаціональних суфіксоїдів, що є виразниками різних значень. Так, відсубстантивний СТ з формантом -маній- характеризується загальним значенням «надмірний потяг, прагнення до чогось, захоплення чимось або кимось», пор.: декретоманія, агентоманія, шпигуноманія, лялькоманія, йо-йоманія, балетоманія, джинсоманія, лєноманія: Чи охопить «йойоманія» Київ? (ВК, 17.08.2009); Сьогодні Німеччна не спить: тут панує справжня Лсноманія (1+1: ТСН, 30.05.10); у російській мові тарантиноман, дипперпломан, битломан: Эту команду знают многие киноманы, точнее тарантиноманы (ОРТ, 05.07.12); Это наши, это битломаны или дипперпломаны... (ОРТ, 17.06.13).

Проведене порівняльне дослідження морфонологічних особливостей словотворення відсубстантивів української та російської мов засвідчує наявність значної кількості спільних рис у творенні нових лексем. Так, характерною особливістю творення нових слів в обох мовах є домінування двох морфонологічних явищ: консонантні чергування фонем за ознакою палатальність / депалатальність та зміна акцентної позиції. Чергування фонем за ознакою палатальність / депалатальність помітна серед інноваційних субстантивів, що позначають діячів як чоловічої, так i жіночої статі (СТ із суфіксом -ець-івець). Зміна акцентної позиції часто трапляється як в українській (похідні із суфіксом -ізацій-/-изацій-, -ацій-, -н' $\boldsymbol{H}^{\prime}-$ та суфіксоїдом -ман-), так і в російській мовах у словотвірних типах на -ец, -ист, -люб. Досить часто в аналізованому матеріалі трапляються новотвори 3 кількома морфонологічними явищами одночасно, що характерне для неелементарних морфонологічних моделей. Перспективу подальшого дослідження словотвірної морфонології нових слів убачаємо у виокремленні моделей, типів і класів нових слів за частиномовною належністю, продуктивністю і регулярністю морфонологічних явищ у неолексемах сучасної української літературної мови, дослідженні морфонологічних особливостей деад'єктивів та девербативів.

\section{Література}

1. Віняр Г. М. Словотворчі тенденції в сучасній українській мові (на матеріалі усного і писемного мовлення 80-х - початку 90-х років XX століття) : автореф. дис. ... канд. філол. наук : спец. 10.02.01 «Українська мова»/ Г. М. Віняр. - Дніпропетровськ, 1992. - 16 с.

2. Демешко І. М. Морфонологічна характеристика неолексем-девербативів у сучасній українській літературній мові / I. М. Демешко // Вісник Дніпропетровського університету. - Серія : Мовознавство. - Дніпропетровськ : Вид-во ДНУ, 2013. - Т. 21. - 
№ 11. - Вип. 19. - Т. 3. - С. 44-52.

3. Земская Е. А. Активные процессы современного словопроизводства / Е. А. Земская // Русский язык конца ХХ столетия (1985-1995). - [2-е изд.]. - М. : Языки русской культуры, 2000. - С. 90-141.

4. Попова Т. В. Неология и неография современного русского языка : [учеб. пособие] / Т. В. Попова, Л. В. Рацибурская, Д. В. Гугунава. - М. : Флинта : Наука, 2005. - 168 с.

5. Русский язык конца ХХ столетия (1985-1995) / [под ред. Е. А. Земской]. - [2-е изд.]. - М. : Языки русской культуры, 2000. - 480 с.

6. Стишов О. А. Українська лексика кінця XX століття: (На матеріалі мови засобів масової інформації). - [2-е вид., переробл.]. - К. : Пугач, 2005. - 388 с. 